Article

\title{
Breaking Dormancy and Effects of Shade Level and NPK Fertilizer Rates on Yield of Zingiber zerumbet (L.) Smith (Lempoyang)
}

\author{
Suzanne Goh ${ }^{1, *}$, Thohirah Lee Abdullah ${ }^{1}$, Siti Aishah Hassan ${ }^{1}$ and Johnson Stanslas ${ }^{2}$ \\ 1 Department of Crop Science, Faculty of Agriculture, University Putra Malaysia, Serdang 43400, \\ Selangor Darul Ehsan, Malaysia; thohirah@upm.edu.my (T.L.A.); s_aishah@upm.edu.my (S.A.H.) \\ 2 Department of Medicine, Faculty of Medicine and Health Sciences, University Putra Malaysia, \\ Serdang 43400, Selangor Darul Ehsan, Malaysia; jstanslas@yahoo.co.uk \\ * Correspondence: suzanne_9312@yahoo.com; Tel.: +60-111-061-9312
}

Received: 15 October 2018; Accepted: 31 October 2018; Published: 12 December 2018

Abstract: Zingiber zerumbet (L.) Smith, known as Lempoyang in Malaysia, belongs to the family Zingiberaceae. Previous studies on Lempoyang mainly focused on the chemical properties and biological activities of the rhizome extracts of this plant. Despite the tremendous demand for the rhizomes of $Z$. zerumbet, there is a lack of information on cultivation practices and a scarcity of planting materials. By using the pre-soaked technique, the challenges posed by Z. zerumbet dormancy can be overcome, obtaining good quality and uniform planting material throughout the year. Besides that, it is also crucial to determine the optimum shade level and NPK fertilizer rates to obtain a high yield and good quality rhizomes of Lempoyang. Six concentrations of 6-benzylaminopurine (BAP, 0, 50, 100, 150, 200, and $250 \mathrm{mg} / \mathrm{L}$ ) and ethephon $(0,150,300,450,600$, and $750 \mathrm{mg} / \mathrm{L}$ ) were tested to evaluate their effects on breaking rhizome dormancy. Three different shade levels (full sun, $30 \%$, and $50 \%$ shade levels) and four combinations of Nitrogen $(\mathrm{N})$, phosphorus $(\mathrm{P})$, and potassium $(\mathrm{K})$ (NPK) fertilizer at different rates were evaluated to study their effects on plant growth and yield performance. The results showed that BAP at $100 \mathrm{mg} / \mathrm{L}$ and ethephon at $300 \mathrm{mg} / \mathrm{L}$ performed better than the other compound concentrations tested in promoting the breaking of bud dormancy. A significant interaction effect was observed between shade levels and NPK fertilizer rates in all the growth parameters examined, except for the number of tillers per plant. Plants grown under $30 \%$ shade with NPK 4 produced the highest rhizome fresh weight, dry weight, and yield, but plants grown under $50 \%$ shade with NPK 4 showed the highest plant height and number of tillers per plant.

Keywords: Zingiber zerumbet; dormancy; shade level; fertilizer; rhizome yield; NPK

\section{Introduction}

Zingiber zerumbet (L.) Smith is commonly found in the lowland forest of Malaysia where it grows naturally on hill slopes or in damp and shaded areas. This native rhizomatous herb has high medicinal values and is also used as food flavoring. Previous studies on Lempoyang have mainly focused on the chemical properties and biological activities of the rhizome extracts of this plant, and it was reported that $Z$. zerumbet has many biological activities such as anti-inflammatory [1], antinociceptive [2], antitumor [3], and others. However, the agronomic practices are still not well studied, and there is insufficient knowledge of the required growing conditions. Basic information on breaking bud dormancy, light requirement, and nutrient requirement is still lacking. Z. zerumbet undergoes dormancy for a period of 1 to 2 months, which causes rhizomes to be susceptible to fungal diseases which also affect the quality of the plant and the cropping cycles. Breaking bud dormancy of Z. zerumbet rhizome 
can solve the problems faced during the dormancy period and could provide good quality planting materials throughout the year.

Previous studies reported that plant growth regulators such as cytokinins and auxins play an important role in breaking dormancy. Cytokinins are known to induce bud break in many kinds of plants on both aerials and below-ground parts [4]. In tissue culture, it was reported that medium with 6-benzylaminopurine (BAP) and combinations with other phytohormones successfully induced micro-rhizomes of Zingiber officinale and Zingiber cassumunar [5,6]. Ethephon (2-chloroethyl phosphoric acid) is an ethylene-releasing compound which is widely used as a plant growth regulator. Its effect will vary depending on the plant species, its chemical concentration, and the timing and duration of the application of exogenous ethylene or the ethephon solution [7]. Endogenous cytokinins and auxins exhibited great influence on initiation and development in the rhizomes of Z. officinale [8], while ethephon used in pre-planting soaking and foliar treatment was able to promote shoot emergence and increased shoot numbers in Z. officinale $[9,10]$. On the basis of the previous literature, plant growth regulators like BAP and ethephon were believed to be able to break rhizome dormancy of Z. zerumbet. In addition, there is still no report available related to BAP and ethephon ability to break rhizome dormancy of $Z$. zerumbet using the pre-soaked technique.

Light intensity is an important factor not only in the photosynthesis process and food production but also in plant growth and development. The photosynthetic capacity can be increased by increasing the light intensity, and plant growth will be enhanced at the same time [11,12]. Therefore, the rhizome yield of Z. officinale was reduced when growing under a high shade level $[13,14]$. To increase the yield of crops, the application of fertilizers is essential, and the adequate amount of fertilizers to be applied to boost rhizome yield should be known to avoid wastage. Increasing fertilizer rates significantly increase the rhizome yield in the Zingiberaceae family, such as in turmeric (Curcuma longa L.) and ginger (Z. officinale) $[15,16]$. Three major nutrients which are Nitrogen $(\mathrm{N})$, phosphorus $(\mathrm{P})$, and potassium $(\mathrm{K})$ play a very important role in plant growth, yield, and plant quality [17]. Z. zerumbet is a long-term exhaustive crop which requires a high amount of fertilizer. Nutrient availability is a very important factor in crop development and yield production, therefore the optimum fertilizer rate to produce the maximum yield is crucial. However, there is a lack of information on the optimum shade levels and fertilizer rates for maximum growth and rhizome yield of Lempoyang. Therefore, this study was performed to evaluate the potential and the optimum concentration of BAP and ethephon to break rhizome dormancy and to determine the effect of various shade levels and NPK fertilizer rates on the growth and production of rhizome in Z. zerumbet.

\section{Materials and Methods}

\subsection{Plant Materials}

The rhizomes of Z. zerumbet were bought from Kizaherb Enterprise, Kuala Krau in Pahang, Malaysia. Dormant rhizomes were used for the dormancy study, while some rhizomes were propagated to produce more planting materials. The plants were then sent to the Herbarium of the Institute of Bioscience, University Putra Malaysia (UPM), to be identified and kept as voucher specimens (SK 3183/17). The plants were grown in Ladang 2, UPM, for 6 months, under different growing conditions.

\subsection{Breaking Dormancy}

A selection of rhizomes was made on the basis of their dormant state, number of eye buds, and size. Only rhizomes that were dormant, with at least three eye buds, and with a length of $3-5 \mathrm{~cm}$ were used. Rhizomes were treated with the fungicide Benlate ${ }^{\circledR}$ (Benomyl) for $30 \mathrm{~min}$ and were air-dried before being soaked in treatment solutions. BAP at 0, 50, 100, 150, 200, and $250 \mathrm{mg} / \mathrm{L}$ and Ethephon at $0,150,300,450,600$, and $750 \mathrm{mg} / \mathrm{L}$ were selected, on the basis of a literature review. The rhizomes were soaked in treatment solutions for $30 \mathrm{~min}$ and placed on moistened cotton in transparent containers in aseptic conditions. The containers were arranged in Completely Randomized Design (CRD) and 
maintained at $25 \pm 2{ }^{\circ} \mathrm{C}, 16$ h daily illumination with 1000 lux of white fluorescent light for 30 days. Two separate experiments were conducted simultaneously with four replications. Each replication consisted of two rhizomes as an experimental unit that made up a total of 96 rhizomes. The breaking dormancy study was conducted twice at different times, using the same method and conditions. Data on the number of days to visible buds, mean number of buds, mean number of shoots, percentage of buds sprouted, and rhizome weight were collected.

\subsection{Shade Levels and NPK Fertilizer Rates on Growth and Rhizome Yield}

One-month-old seedlings were planted in $18 \times 20$ inches polybags and grown under three different shade levels $(0 \%, 30 \%$, and 50\%). The three major nutrients (NPK) with different combination rates were evaluated $0.5,1,1.5$, and 2 times the base recommended rate for NPK 2 (Table 1). A media mixture was used with a combination of soil, cocopeat, burnt rice husk, and topsoil at the ratio of 1:1:1:1. The experimental design used was a split-plot design laid in a randomized complete block design (RCBD). The main plots were three shade levels, and the sub-plots were four NPK fertilizer rates. Four replications with a total of 144 plants were used for this study. An irrigation system was fixed to water the plants once a day in the evening. Weeding was done manually by hand. Fertilization was divided equally with three-month intervals, and the first fertilizer was applied two weeks after planting. Growth parameters were collected before harvesting. The plants were harvested in the sixth month after planting. The harvested rhizomes were washed and air-dried for $30 \mathrm{~min}$. The fresh weight of the harvested rhizomes was recorded. Freshly harvested rhizomes were then put into an oven for 4 days for drying, and the rhizomes' dry weight was recorded.

Table 1. Combination of Nitrogen $(\mathrm{N})$, phosphorus (P), and potassium (K) (NPK) fertilizers rates.

\begin{tabular}{cc}
\hline Treatments & NPK (kg/ha/year) \\
\hline NPK 1 & $(30: 35: 62)$ \\
NPK 2 & $(60: 70: 115)$ \\
NPK 3 & $(90: 105: 172)$ \\
NPK 4 & $(120: 140: 230)$ \\
\hline
\end{tabular}

\subsection{Statistical Analysis}

The collected data were subjected to analysis of variance (ANOVA) using SAS program version 9.2. The means were compared by Duncan's Multiple Range Test (DMRT) when the F-test of the ANOVA for the treatments was significant at the $p<0.05$. All data of breaking rhizome dormancy were arcsine-transformed prior to ANOVA.

\section{Results and Discussion}

\subsection{The Effects of BAP and Ethephon on Breaking the Rhizome Dormancy of Z. zerumbet}

In Experiment 1, there were significant effects of different BAP concentrations on the number of days to visible buds, the mean number of buds, the mean number of shoots, and the percentage of buds sprouted at $p<0.05$. Even though BAP at the highest concentration $(250 \mathrm{mg} / \mathrm{L})$ was able to decrease the number of days to visible buds, the mean number of buds and shoots were also reduced. As regards the number of shoots, BAP at concentration $100 \mathrm{mg} / \mathrm{L}$ or less induced a higher number of shoots than at higher concentrations and, concerning the bud sprouting percentage, BAP $100 \mathrm{mg} / \mathrm{L}$ produced the highest percentage $(62.50 \%)$ which was $37.5 \%$ higher than that observed in the control. All five levels of BAP treatments did not produce any significant effects on the rhizome weight (Table 2). BAP has been successfully used to break the dormancy of various geophytic units [18]. In breaking the dormancy of gladiolus cv Friendship corms, $100 \mathrm{mg} / \mathrm{L}$ was reported as the optimum concentration of BAP [19]. BAP treatments were slightly more successful in breaking the dormancy of Heliconia compared to the absence of treatment [4]. In this study, BAP at $100 \mathrm{mg} / \mathrm{L}$ induced the highest number of shoots, which is similar to the results obtained with Z. officinale and turmeric plants 
in tissue culture [20,21]. This study suggests that BAP at a concentration higher than $200 \mathrm{mg} / \mathrm{L}$ is not recommended as it reduced the mean number of shoots and the percentage of buds sprouted. Among all the tested concentrations of BAP, $100 \mathrm{mg} / \mathrm{L}$ showed a better performance in breaking bud dormancy, as it produced the highest percentage of bud sprouted and the highest number of shoots, even though it did not produce any significant difference in the number of days to visible buds when compared to the control. On the other hand, ethephon at different concentrations showed significant effects on all parameters, except for the rhizome weight in Experiment 2 (Table 3). Increasing concentrations of ethephon from 300 to $600 \mathrm{mg} / \mathrm{L}$ significantly reduced the number of days to visible buds at $p<0.05$. The highest mean number of buds was achieved with ethephon $300 \mathrm{mg} / \mathrm{L}(2)$. Ethephon at $300 \mathrm{mg} / \mathrm{L}$ and $600 \mathrm{mg} / \mathrm{L}$ showed the same effect on the mean number of shoots (1.25), which was significantly different from that of other treatments. The dormant rhizomes that were treated with ethephon at less than $700 \mathrm{mg} / \mathrm{L}$ showed a higher percentage of bud sprouted when compared with untreated rhizomes. Among all the concentrations, ethephon at $300 \mathrm{mg} / \mathrm{L}$ produced the highest percentage of bud sprouted $(72.50 \%)$, a value significantly different from those obtained with ethephon at $750 \mathrm{mg} / \mathrm{L}$ and in the control. Ethephon released ethylene when absorbed by the plant tissues and induced an increment in respiration, whereby glucose was broken down, and metabolic energy was synthesized. When the metabolic energy was synthesised, the rhizomes were able to break dormancy [7,22]. The effectiveness of ethylene to break dormancy was shown in the rhizomes of Rheum rhabarbarum L. and Globba winitti and in the tuber of Helianthus tuberosus L. [23-25]. In Z. officinale, ethephon at $750 \mathrm{mg} / \mathrm{L}$ was demonstrated to produce the highest number of shoot production and the lowest shoot height [10]. However, in this study, ethephon was more efficient in breaking bud dormancy at lower concentrations. Ethephon at $300 \mathrm{mg} / \mathrm{L}$ determined the lowest number of days to visible buds, the highest number of buds, and the highest percentage of bud sprouted. This might be due to the sensitivity of Z. zerumbet to ethephon. Higher concentrations of ethephon were associated with a higher number of days to visible buds, but this may vary depending on the plant type and the combination with other phytohormones.

Table 2. The effect of different concentrations of 6-benzylaminopurine (BAP) on the number of days to visible buds, mean number of buds, mean number of shoots, percentage of buds sprouted, and rhizome weight of Z. zerumbet.

\begin{tabular}{cccccc}
\hline $\begin{array}{c}\text { Treatment } \\
\text { (mg/L) }\end{array}$ & $\begin{array}{c}\text { Days to } \\
\text { Visible Buds }\end{array}$ & $\begin{array}{c}\text { Mean Number } \\
\text { of Buds }\end{array}$ & $\begin{array}{c}\text { Mean Number } \\
\text { of Shoots }\end{array}$ & $\begin{array}{c}\text { Percentage of } \\
\text { Buds Sprouted }\end{array}$ & $\begin{array}{c}\text { Rhizome } \\
\text { Weight (g) }\end{array}$ \\
\hline Control & $17.00 \mathrm{a}$ & $0.88 \mathrm{a}$ & $0.50 \mathrm{~b}$ & $25.00 \mathrm{c}$ & $3.68 \mathrm{a}$ \\
BAP 50 & $13.25 \mathrm{~b}$ & $1.00 \mathrm{a}$ & $0.75 \mathrm{ab}$ & $40.63 \mathrm{ab}$ & $4.71 \mathrm{a}$ \\
BAP 100 & $10.25 \mathrm{~b}$ & $1.13 \mathrm{a}$ & $0.88 \mathrm{a}$ & $62.50 \mathrm{a}$ & $4.93 \mathrm{a}$ \\
BAP 150 & $14.88 \mathrm{~b}$ & $1.25 \mathrm{a}$ & $0.38 \mathrm{bc}$ & $16.63 \mathrm{~b}$ & $4.89 \mathrm{a}$ \\
BAP 200 & $22.63 \mathrm{a}$ & $1.38 \mathrm{a}$ & $0.25 \mathrm{c}$ & $18.75 \mathrm{~b}$ & $4.43 \mathrm{a}$ \\
BAP 250 & $7.13 \mathrm{c}$ & $0.63 \mathrm{~b}$ & $0.38 \mathrm{bc}$ & $18.75 \mathrm{~b}$ & $4.31 \mathrm{a}$ \\
\hline
\end{tabular}

Means within the same column followed by a common letter are not significantly different based on DMRT at $(p<0.05)$ level.

Table 3. The effect of different concentrations of ethephon on the number of days to visible buds, mean number of buds, mean number of shoots, percentage of buds sprouted, and rhizome weight of Z. zerumbet.

\begin{tabular}{cccccc}
\hline $\begin{array}{c}\text { Treatments } \\
(\mathbf{m g} / \mathrm{L})\end{array}$ & $\begin{array}{c}\text { Days to } \\
\text { Visible Buds }\end{array}$ & $\begin{array}{c}\text { Mean Number } \\
\text { of Buds }\end{array}$ & $\begin{array}{c}\text { Mean Number } \\
\text { of Shoots }\end{array}$ & $\begin{array}{c}\text { Percentage of } \\
\text { Buds Sprouted }\end{array}$ & $\begin{array}{c}\text { Rhizome } \\
\text { Weight (g) }\end{array}$ \\
\hline Control & $17.00 \mathrm{a}$ & $0.88 \mathrm{~b}$ & $0.25 \mathrm{~b}$ & $25.00 \mathrm{~b}$ & $3.68 \mathrm{~b}$ \\
Etp150 & $21.00 \mathrm{a}$ & $0.75 \mathrm{~b}$ & $0.13 \mathrm{~b}$ & $62.50 \mathrm{a}$ & $5.41 \mathrm{a}$ \\
Etp300 & $10.63 \mathrm{~b}$ & $2.00 \mathrm{a}$ & $1.25 \mathrm{a}$ & $72.50 \mathrm{a}$ & $4.81 \mathrm{a}$ \\
Etp450 & $11.25 \mathrm{~b}$ & $1.13 \mathrm{ab}$ & $0.75 \mathrm{~b}$ & $50.00 \mathrm{a}$ & $4.74 \mathrm{a}$ \\
Etp600 & $12.25 \mathrm{~b}$ & $1.38 \mathrm{ab}$ & $1.25 \mathrm{a}$ & $67.50 \mathrm{a}$ & $4.80 \mathrm{a}$ \\
Etp750 & $24.25 \mathrm{a}$ & $0.63 \mathrm{~b}$ & $0.25 \mathrm{~b}$ & $12.50 \mathrm{~b}$ & $5.72 \mathrm{a}$ \\
\hline
\end{tabular}

Means within the same column followed by a common letter are not significantly different based on DMRT at $(p<0.05)$ level. 


\subsection{Interaction Effects of Shade Levels and NPK Fertilizer Rates on the Growth and Rhizome Yield of Z. zerumbet}

The interaction effects of shade levels and NPK fertilizer rates were found to be significant for all parameters, except for the number of tillers per plant. Plant height was significantly affected by the interaction of shade levels and NPK fertilizer rates (Table 4). Under $50 \%$ shade level, plant height was in the following order: NPK $4(48.78 \mathrm{~cm})>\operatorname{NPK} 3(35.75 \mathrm{~cm})>\operatorname{NPK} 2(31.85 \mathrm{~cm})>\operatorname{NPK} 1(29.25 \mathrm{~cm})$. A shade level of $30 \%$ and full sun reacted differently with NPK fertilizer rates, regarding plant height. Plants grown under $30 \%$ shade were the tallest when treated with NPK $4(40.75 \mathrm{~cm})$, but, under full sun condition, NPK 3- and NPK 4-treated plants were both taller than plants treated with other NPK fertilizer rates and showed a non-significant difference between them (Figure 1). The plants tended to grow taller when the shade level increased, as a result of the elongation of the internodes. The height of sweet pepper and turmeric was also reported to increase when the shade was increased [26,27]. Increasing the shade levels significantly increased the number of tillers. As for main effect, the highest mean number of tillers was obtained under $50 \%$ shade (5.00) while the highest NPK fertilizer rate, i.e., NPK 4 produced highest mean number of tiller at 5.17. However, there was no interaction effect on the number of tillers at $p<0.05$. The number of leaves per tiller and the leaf area per plant dependent on the interaction effect between shade level and NPK fertilizer rates. The number of leaves in plants grown under 50\% shade was the highest when the plants were treated with NPK 3 (30.31) and NPK 4 (31.63), with no significant difference between them. Furthermore, NPK 4 produced the highest number of leaves in 30\% shade (30.00) and full sun (25.13), respectively. When the plants were grown under $50 \%$ shade and were treated with NPK 4, the highest leaf area per plant was obtained $\left(132.41 \mathrm{~cm}^{2}\right)$. In addition, the lowest leaf area per plant was obtained in plants treated with NPK 1 and planted under full sun $\left(57.33 \mathrm{~cm}^{2}\right)$ and $30 \%$ shade level $\left(66.10 \mathrm{~cm}^{2}\right)$. The significant interaction between shade and NPK fertilizer rates produced a varying effect on the leaf area per plant in Lempoyang. The growth parameters of plants grown under shade were better and improved compared to plants grown under full sun. A high light intensity causes damage on shade-lover plants, which explains the poor growth performance of Z. zerumbet under $0 \%$ shade level. A reduction of the leaf area was also observed in the open field, which may be due to a higher radiation level that damaged the photosynthetic pigment [28]. When a plant's leaf area reduces, photosynthesis will eventually decrease, thus leading to poor rhizome yield. The responses of $Z$. zerumbet to different shade levels will probably vary in different geographical areas, seasons, and cultivars. This study found that there were significant interaction effects on rhizome fresh weight, dry weight, and yield. When Lempoyang was exposed to $30 \%$ shade level and NPK 4, the highest rhizome fresh weight, dry weight, and yield were obtained (Table 4). On the other hand, under 50\% shade level, NPK 3 performed better regarding rhizome fresh weight and dry weight, and NPK 4 induced a reduction of rhizome yield. The plants grown under full sun showed a lower rhizome yield when NPK fertilizer rates were reduced; however, NPK3 and NPK 4 showed similar effects on rhizome fresh weight in full sun condition. Our results are supported by previous studies. Increasing the shade level was reported to produce a higher biomass in turmeric and sweet pepper $[26,27,29]$. In contrast, the yield of $Z$. officinale was reduced when the plant was grown under high shade level $[13,14]$. The findings of this study confirm that $Z$. zerumbet is a true shade-type species that grows best under low light intensity, a condition similar to its native shaded habitat. Increasing the fertilizer rate increased all the growth parameters considered, in all shade levels. The increasing rates of NPK increased the nutrient uptake of the plants, and this might be the reason why higher fertilizer rates produced higher rhizome yields. The study on Z. officinale and C. longa L. also reported that increasing fertilizer rates produced higher rhizome yields $[16,30]$. The results of this study indicate that the growth and rhizome yield of Z. zerumbet depends on the shade level and the applied NPK fertilizer rates. The interaction study revealed a general trend of yield increase with the increase of NPK fertilizer rates and shade levels. The combination of 30\% shade level and NPK 4 was able to produce the best plant growth and the maximum rhizome yield of Z. zerumbet. 
Table 4. Effects of shade levels and NPK fertilizer rates on growth parameters, rhizome fresh weight, rhizome dry weight, and rhizome yield of Z. zerumbet.

\begin{tabular}{|c|c|c|c|c|c|c|c|}
\hline Treatments & Plant Height (cm) & $\begin{array}{c}\text { Number of Tillers } \\
\text { per Plants }\end{array}$ & $\begin{array}{l}\text { Average Number of } \\
\text { Leaves per Tiller }\end{array}$ & $\begin{array}{l}\text { Leaf Area per } \\
\text { Plant }\left(\mathrm{cm}^{2}\right)\end{array}$ & $\begin{array}{c}\text { Rhizome Fresh } \\
\text { Weight (g/plant) }\end{array}$ & $\begin{array}{c}\text { Rhizome Dry } \\
\text { Weight (g/plant) }\end{array}$ & $\begin{array}{l}\text { Yield (Tonne } \\
\text { per Hectare) }\end{array}$ \\
\hline \multicolumn{8}{|l|}{ Shade levels $\left(\mu \mathrm{mol} \mathrm{m} \mathrm{s}^{-1}\right)$} \\
\hline Full sun & $29.47 \pm 1.80 \mathrm{~b}$ & $4.40 \pm 0.39 \mathrm{~b}$ & $20.25 \pm 0.91 c$ & $67.22 \pm 1.35 c$ & $157.04 \pm 2.05 \mathrm{ab}$ & $34.39 \pm 1.70 c$ & $0.44 \pm 0.01 \mathrm{ab}$ \\
\hline $30 \%$ Shade & $30.03 \pm 1.48 b$ & $4.72 \pm 0.77 b$ & $26.32 \pm 0.93 b$ & $84.56 \pm 2.33 \mathrm{~b}$ & $159.37 \pm 6.27 \mathrm{a}$ & $38.46 \pm 1.37 b$ & $0.44 \pm 0.02 \mathrm{a}$ \\
\hline $50 \%$ Shade & $36.41 \pm 1.39 \mathrm{a}$ & $5.79 \pm 0.71 \mathrm{a}$ & $29.24 \pm 1.01 \mathrm{a}$ & $100.71 \pm 2.74 \mathrm{a}$ & $154.73 \pm 2.89 \mathrm{~b}$ & $41.41 \pm 1.78 \mathrm{a}$ & $0.43 \pm 0.01 b$ \\
\hline \multicolumn{8}{|l|}{ NPK rates (kg/ha/year) } \\
\hline NPK 1 (30:35:62) & $24.75 \pm 4.58 \mathrm{~d}$ & $3.83 \pm 1.40 \mathrm{c}$ & $21.79 \pm 3.48 \mathrm{~d}$ & $68.25 \pm 4.58 \mathrm{~b}$ & $117.56 \pm 14.84 \mathrm{~d}$ & $29.13 \pm 5.21 \mathrm{~d}$ & $0.33 \pm 0.04 \mathrm{~d}$ \\
\hline NPK 2 (60:70:115) & $28.55 \pm 3.35 c$ & $4.70 \pm 1.39 \mathrm{~b}$ & $24.09 \pm 1.41 \mathrm{c}$ & $76.11 \pm 3.35 b$ & $141.88 \pm 8.09 c$ & $33.85 \pm 3.48 c$ & $0.39 \pm 0.02 c$ \\
\hline NPK 3 (90:105:172) & $33.22 \pm 9.78 b$ & $5.06 \pm 1.99 \mathrm{~b}$ & $26.27 \pm 1.57 b$ & $87.16 \pm 9.78 \mathrm{a}$ & $176.58 \pm 6.02 \mathrm{~b}$ & $42.99 \pm 5.49 b$ & $0.49 \pm 0.01 b$ \\
\hline NPK 4 (120:140:230) & $41.36 \pm 7.94 \mathrm{a}$ & $6.29 \pm 2.73 \mathrm{a}$ & $28.92 \pm 4.89 a$ & $105.13 \pm 7.94 \mathrm{a}$ & $192.17 \pm 15.87 \mathrm{a}$ & $46.36 \pm 5.23 a$ & $0.53 \pm 0.04 a$ \\
\hline \multicolumn{8}{|l|}{$F$ value } \\
\hline Shade levels (S) & $82.56^{* * *}$ & $15.49 * *$ & $296.42 * * *$ & $1074.82 * * *$ & $5.83 *$ & $42.73 * *$ & $5.83 *$ \\
\hline NPK rates (NPK) & $217.12 * * *$ & $34.51^{* * *}$ & $84.49^{* * *}$ & $317.22 * * *$ & $568.50^{* * *}$ & $336.48 * * *$ & $568.50 * * *$ \\
\hline $\mathrm{S} \times \mathrm{NPK}$ & $14.45^{* * *}$ & 1.44 N.S. & $4.15 *$ & $28.11 * *$ & $62.84^{* * *}$ & $11.58^{* * *}$ & $63.24 * * *$ \\
\hline CV $(\%)$ & 5.26 & 12.09 & 4.53 & 3.69 & 3.11 & 3.95 & 3.06 \\
\hline
\end{tabular}

Values are means \pm SD. Same letter within the same column indicate no significant difference $(p<0.05)$. The means separations were determined using DMRT. F value represented with $*=p<0.05,{ }^{* *}=p<0.01,{ }^{* * *}=p<0.001$; N.S. $=$ not significant. 


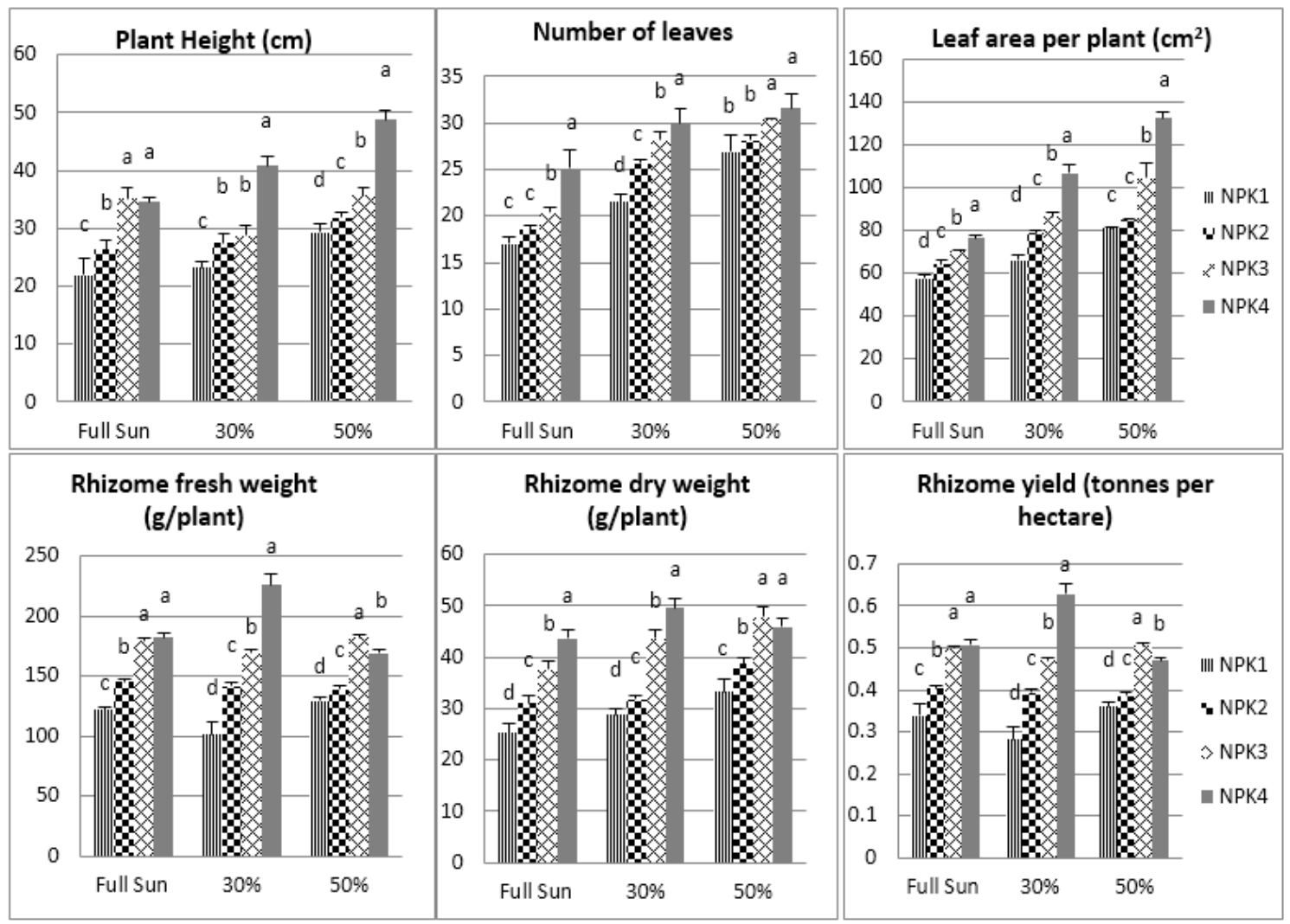

Figure 1. Effect of shade levels and NPK fertilizer rates on growth parameters, rhizome fresh weight, rhizome dry weight, and rhizome yield of $Z$. zerumbet. The means separations within each shade level were determined using DMRT at $(p<0.05)$ level.

\section{Conclusions}

The pre-soaked technique is an easy and practical way to break bud dormancy and can be applied in the production of $Z$. zerumbet. The use of BAP and ethephon was successful in breaking the bud dormancy of $Z$. zerumbet. BAP at $100 \mathrm{mg} / \mathrm{L}$ produced the highest percentage of bud sprouted, while ethephon at $300 \mathrm{mg} / \mathrm{L}$ was associated with the earliest time to visible eye buds, the highest number of shoot, and the highest percentage of bud sprouted. The findings of this study show that $\mathrm{BAP}$ at $100 \mathrm{mg} / \mathrm{L}$ and ethephon at $300 \mathrm{mg} / \mathrm{L}$ are the most effective to break the rhizome bud dormancy of Lempoyang. Shade levels and NPK fertilizers rates showed interaction effects on the growth and yield of Z. zerumbet. Growing Z. zerumbet under 30\% shade in the presence of NPK 4 (120:140:230 NPK $\mathrm{kg} / \mathrm{ha}$ /year) was found to be the best cultural practice to improve growth performance and rhizome yield. On the basis of these findings, cultivation of $Z$. zerumbet can be improved, and its planting in Malaysia can be encouraged to overcome the shortage of planting materials and fulfill the market demands.

Author Contributions: S.G. and T.L.A. proposed and designed the study. S.G. carried out the experiment and collected the data. S.A.H. assisted in methodology and statistical analysis. J.S. aided in interpreting the results and discussions. S.G. wrote the manuscript in consultation with T.L.A., S.A.H. and J.S. All authors discussed the results and commented on the manuscript.

Funding: The authors would like to thank the Ministry of Agriculture (MOA) of Malaysia for funding this research under the NKEA Research Grant Scheme (NRGS) with project number NH1015A025.

Acknowledgments: The authors would like to thank all of the individuals that were involved in this study.

Conflicts of Interest: The authors declare no conflict of interest. 


\section{References}

1. Murakami, A.; Hayashi, R.; Takana, T.; Kwon, K.H.; Ohigashi, H.; Safitri, R. Suppression of dextran sodium sulfate-induced colitis in mice by zerumbone, a subtropical ginger sesquiterpene, and nimesulide: Separately and in combination. Biochem. Pharmacol. 2003, 66, 1253-1261. [CrossRef]

2. Sulaiman, M.R.; Mohamad, T.A.S.T.; Mossadeq, W.M.S.; Moin, S.; Yusof, M.; Mokhtar, A.F.; Zakaria, Z.A.; Israf, D.A.; Lajis, N. Antinociceptive activity of the essential oil of Zingiber zerumbet. Planta Med. 2010, 76, 107-112. [CrossRef] [PubMed]

3. Ramos, S.; Alía, M.; Bravo, L.; Goya, L. Comparative effects of food-derived polyphenols on the viability and apoptosis of a human hepatoma cell line (HepG2). J. Agric. Food Chem. 2005, 53, 1271-1280. [CrossRef] [PubMed]

4. Criley, R. Method of application affects effectiveness of cytokinin in inducing bud break on heliconia rhizomes. Hortic. Dig. 2001, 106.

5. Chirangini, P.; Sharma, G. In vitro propagation and microrhizome induction in zingiber cassumunar (ROXB.) an antioxidant-rich medicinal plant. J. Food Agric. Environ. 2005, 3, 139-142.

6. Swarnathilaka, D.; Kottearachchi, N.; Weerakkody, W. Factors affecting on induction of microrhizomes in ginger (Zingiber officinale Rosc.), cultivar local from Sri Lanka. Br. Biotechnol. J. 2016, 12, 1-7. [CrossRef]

7. Khuankaew, T.; Ohyama, T.; Ruamrungsri, S. Effects of Ethephon Application on Growth and Development of Curcuma Alismatifolia Gagnep. 2009. Available online: http://dspace.lib.niigata-u.ac.jp/dspace/bitstream/ 10191/13095/1/62 (accessed on 1 November 2018).

8. Ravishankar, C.; Muthuswamy, S. Studies on the endogenous hormonal changes in leaf and rhizome of ginger. South Indian Hortic. 1984, 32, 347-351.

9. Islam, A.; Asher, C.; Edwards, D. Germination and early growth of ginger (Zingiber officinale Roscoe), 2: Effects of 2-chloroethyl phosphonic acid or elevated temperature pretreatments. Trop. Agric. 1978, 55, v127-134(2).

10. Furutani, S.; Nagao, M. Influence of daminozide, gibberellic acid, and ethephon on flowering, shoot growth, and yield of ginger. HortScience 1986, 21, 428-429.

11. Abrams, M.D.; Mostoller, S.A. Gas exchange, leaf structure and nitrogen in contrasting successional tree species growing in open and understory sites during a drought. Tree Physiol. 1995, 15, 361-370. [CrossRef]

12. Makino, A.; Sato, T.; Nakano, H.; Mae, T. Leaf photosynthesis, plant growth and nitrogen allocation in rice under different irradiances. Planta 1997, 203, 390-398. [CrossRef]

13. Sreekala, G.; Jayachandran, B. Influence of shade regimes on the physiological parameters of ginger. J. Spices Aromat. Crops 2002, 11, 30-34.

14. Kratky, B.; Bernabe, C.; Arakaki, E.; White, F.; Miyasaka, S. Shading Reduces Yields of Edible Ginger Rhizomes Grown in Sub-Irrigated Pots; University of Hawaii: Honolulu, HI, USA, 2013.

15. Akhter, S.; Noor, S.; Islam, M.; Masud, M.; Talukder, M.; Hossain, M. Effect of potassium fertilization on the yield and quality of ginger (Zingiber officinale) grown on a k deficient terrace soil of level barind tract (AEZ 25) in northern bangladesh. Res. Find. E-Ifc 2013, 35, 13-18.

16. Akamine, H.; Hossain, M.A.; Ishimine, Y.; Yogi, K.; Hokama, K.; Iraha, Y.; Aniya, Y. Effects of application of $\mathrm{n}, \mathrm{p}$ and $\mathrm{k}$ alone or in combination on growth, yield and curcumin content of turmeric (Curcuma longa $\mathrm{L}$.). Plant Prod. Sci. 2007, 10, 151-154. [CrossRef]

17. Ivonyi, I.; Izsoki, Z.; van der Werf, H.M. Influence of nitrogen supply and $\mathrm{p}$ and $\mathrm{k}$ levels of the soil on dry matter and nutrient accumulation of. J. Int. Hemp Assoc. 1997, 4, 84-89.

18. Vlahos, J. Effects of GA3 and BA on Two Cultivars of Achimenes Longiflora Under Two Levels of Irradiance. In Proceedings of the II Symposium on Growth Regulators in Floriculture, Skierniewice, Poland, 30 July-4 August 1984; Volume 167, pp. 225-236.

19. Gowda, J. Effect of ethrel and benzyladenine on breaking dormancy in gladiolus cormels. In Floriculture Technology, Trades and Trends; Oxford and IBH Publishing Co. Pvt. Ltd.: Calcutta, India, 1994; pp. 203-204.

20. Balachandran, S.M.; Bhat, S.R.; Chandel, K.P.S. In vitro clonal multiplication of turmeric (Curcuma spp.) and ginger (Zingiber officinale Rosc.). Plant Cell Rep. 1990, 8, 521-524. [CrossRef]

21. Rajani, C. Micro Propagation of Ginger (Zingiber officinale Rosc.). Master's Thesis, University of Agricultural Sciences, Dharwad, India, 2006. 
22. Dole, J.M.; Wilkins, H.F. Floriculture: Principles and Species; Prentice-Hall Inc.: Upper Saddle River, NJ, USA, 1999.

23. Rayirath, U.P.; Lada, R.R.; Caldwell, C.D.; Asiedu, S.K.; Sibley, K.J. Role of ethylene and jasmonic acid on rhizome induction and growth in Rhubarb (Rheum rhabarbarum L.). Plant Cell Tissue Organ Cult. 2011, 105, 253-263. [CrossRef]

24. Paz, M.D.P. Rhizome Manipulation Affects Growth and Development of Ornamental Gingers. Master's Thesis, Louisiana State University, Baton Rouge, LA, USA, 2003.

25. Kantar, M.; Betts, K.; Hulke, B.S.; Stupar, R.M.; Wyse, D. Breaking tuber dormancy in Helianthus tuberosus L. And interspecific hybrids of Helianthus annuus L. $\times$ Helianthus tuberosus. HortScience 2012, 47, 1342-1346.

26. Srikrishnah, S.; Sutharsan, S. Effect of different shade levels on growth and tuber yield of turmeric (Curcuma longa L.) in the batticaloa district of Sri Lanka. Am. Eurasian J. Agric. Environ. Sci. 2015, 15, 813-816.

27. Rylski, I.; Spigelman, M. Effect of shading on plant development, yield and fruit quality of sweet pepper grown under conditions of high temperature and radlation. Sci. Hortic. 1986, 29, 31-35. [CrossRef]

28. Srikrishnah, S.; Peiris, S.E.; Sutharsan, S. Effect of shade levels on leaf area and biomass production of three varieties of Dracaena sanderiana L. In the dry zone of Sri Lanka. Trop. Agric. Res. 2012, 23, 142-151. [CrossRef]

29. Hossain, M.A.; Akamine, H.; Ishimine, Y.; Teruya, R.; Aniya, Y.; Yamawaki, K. Effects of relative light intensity on the growth, yield and curcumin content of turmeric (Curcuma longa L.) in Okinawa, Japan. Plant Prod. Sci. 2009, 12, 29-36. [CrossRef]

30. Attoe, E.; Osodeke, V. Effects of npk on growth and yield of ginger (Zingiber officinale Roscoe) in soils of contrasting parent materials of cross river state. Electron. J. Environ. Agric. Food Chem. 2009, 8, 1261-1268.

(C) 2018 by the authors. Licensee MDPI, Basel, Switzerland. This article is an open access article distributed under the terms and conditions of the Creative Commons Attribution (CC BY) license (http:/ / creativecommons.org/licenses/by/4.0/). 